\title{
EdITORIALS
}

\section{Legionella, springtime and potting soils}

B de Jong (birgitta.dejong@ecdc.europa.eu) ${ }^{1}$, P Zucs $^{1}$

1. European Centre for Disease Control and Prevention, Stockholm, Sweden

Citation style for this article:

Citation style for this article: de Jong B, Zucs P. Legionella, springtime and potting soils. Euro Surveill. 2010;15(8):pii=19497. Available online: http://www. eurosurveillance.org/ViewArticle.aspx?Articleld=19497

This article has been published on 25 February 2010

Legionnaires' disease has been named after the outbreak in Philadelphia 1976 when a mysterious pneumonia affected a large number of members of the American Legion, a United States military veterans association, which held a gathering at a hotel [1]. Legionella, the bacterium causing the disease was identified several months after this outbreak for the first time. Today we know that there are about 50 different species of Legionella and that not all of them seem to be pathogenic to humans. The vast majority of reported cases are infected with L. pneumophila by inhalation of aerosols (water droplets) containing the bacteria, which is the route of infection for most Legionella cases. This is also described in an article by Joseph and Ricketts in this issue [2].

However, in some instances cases are infected by other Legionella species. A second paper in this issue describes a possible association between handling potting soil and infection with L. longbeachae [3]. As pointed out by the Scottish authors, this has long been well known and documented in Australia and New Zealand. In a soil survey performed in 1989 to 1990 in Australia, 33 (73\%) of 45 potting soil samples tested positive for Legionella; 26 (79\%) of the 33 contained

L. longbeachae [4].

On their homepage, the Auckland Regional Public Health Service as well as the other public health services in Australia and New Zealand offers the following advice on how to minimise the risk of contracting legionellosis [5]:

- Take care when dealing with compost, potting mix and any form of soil or dirt. Read the warning labels on commercially available bags of compost and potting mix.

- To minimise risk, avoid stirring up dust, avoid inhaling dust, dampen the soil/compost before use, wear a dust mask that fits tightly over nose and mouth.

As the Scottish paper indicates, these recommendations may nowadays also be valid in Europe. Cases of L. longbeachae infections often appear as single cases and it could prove difficult to find a link with a commercial potting soil.
According to Steele et al., potting soils are made from different products [4]. In Australia, they tend to consist of composted waste products such as sawdust and hammer milled bark while in Europe peat moss is a major component. It is indicated that the use of different products emanating from wood could facilitate the occurrence of different Legionella bacteria in potting soil. In some parts of Europe, potting soils have bark soil as a component. However, studies from Switzerland have shown that Legionella spp. could also be present in potting soil containing peat moss [6].

Spring will soon come, and with the milder temperatures and increasing amounts of sunlight, gardeners all over Europe will start planting seeds and growing flowers and vegetables. These activities may involve contact with different potting soils and their dust, possibly giving rise to Legionnaires' disease. In this light of spring, cases should not only be questioned about their travel history and contact with aerosols but also if they have had any contact with potting soils or done any gardening.

Clinicians seeing patients with atypical pneumonia should be aware that the Legionella urinary antigen test is only valid for detection of Legionella pneumophila serogroup 1 and therefore other samples should be collected from the patient and submitted to the laboratory in order to be able to identify the causative agent.

In order to be able to estimate how many cases of Legionnaires' disease in Europe are attributable to potting soil, more clinical samples and samples from incriminated potting soils should be cultured. Besides gaining new insight into the epidemiology of this serious disease, the source of each infection could be traced, thus reducing the risk of subsequent cases occurring.

\section{References}

1. Fraser DW, Tsai TR, Orenstein W, Parkin WE, Beecham HJ, Sharrar RG, et al. Legionnaires' disease: description of an epidemic of pneumonia. N Engl J Med. 1977;297(22):1189-97.

2. Joseph CA, Ricketts KD, on behalf of the European Working Group for Legionella Infections. Legionnaires' disease in Europe 2007-2008. Euro Surveill. 2010;15(8):pii=19493. Available from: http://www.eurosurveillance.org/ViewArticle. aspx?Articleld $=19493$ 
3. Pravinkumar SJ, Edwards G, Lindsay D, Redmond S, Stirling J, House R, et al. A cluster of Legionnaires' disease caused by Legionella longbeachae linked to potting compost in Scotland, 2008-2009. Euro Surveill. 2010;15(8):pii=19496. Available from: http://www.eurosurveillance.org/ViewArticle. aspx?Articleld=19496

4. Steele TW, Moore CV, Sangster N. Distribution of Legionella longbeachae serogroup 1 and other Legionella in potting soils in Australia. Appl Environ Microbiol. 1990;56(10):2984-8.

5. Fact Sheet - Legionellosis. New Zealand: Auckland Regional Public Health Service (ARPHS). Available from: www.arphs. govt.nz/notifiable/downloads/legionellosis.pdf

6. Casati S, Giora-Martinoni A, Gaia V. Commercial potting soils as an alternative infections source of Legionella pneumophila and other Legionella species in Switerland. Clin Microbiol Infect. 2009;15(6):571-5. 